\title{
Research
}

\section{Distribution Patterns of Begonia species in the Nepal Himalaya}

\author{
Sangeeta Rajbhandary ${ }^{1 *}$, Mark Hughes ${ }^{2}$ and Krishna K. Shrestha ${ }^{1}$ \\ ${ }^{1}$ Central Department of Botany, Tribhuvan University, Kirtipur, Kathmandu, Nepal \\ ${ }^{2}$ Royal Botanic Garden Edinburgh, 20a Inverleith Row, Edinburgh, U.K, EH3 5LR
}

\begin{abstract}
The 29 Nepalese species of the pantropical genus Begonia largely belong to 2 sections, Begonia sect. Diploclinium and Begonia sect. Platycentrum. The former comprises tuberous species which occur along the Himalayan range. They die back during the dry season and their flowering time is strongly constrained by the onset of the monsoon. The latter comprises evergreen rhizomatous species some of which extend their distribution into more aseasonal areas such as Indo-China. They have a more extended flowering period which is not strictly constrained by the monsoon. There is a gradient of Begonia species richness increasing from west to east across Nepal, in relation to the increased intensity of the monsoon in the east.
\end{abstract}

Key-words: Distribution modelling, geophytes, monsoon, phenology, species richness.

\section{Introduction}

The genus Begonia is pantropically distributed, with the exception of tropical Australia, and is most abundant in Southeast Asia and the Neotropics (Doorenbos et al. 1998; Heywood et al. 2007). Irmscher (1925) recognized two broad centres of diversity for the genus, the first of which ranges from Mexico to the Andes and Brazil, while the second spans the eastern Himalaya, mountains of Indo-China, the Malay Archipelago, the Philippines and New Guinea. Although broad and general distributions patterns of Begonia species and sections within Asia are becoming apparent (Doorenbos et al. 1998; Uddin 2007; Hughes 2007), there have been no analytical studies based on geo-referenced specimen data. The Himalaya is an important area in terms of its position at the centre of several different floristic regions (Bhuju et al. 2007), and a detailed understanding of plant distributions within the region is key to understanding the biogeography of the Himalayan flora both locally and in a broader context. As Begonia species

*Corresponding author, e-mail address: imogine3@gmail.com are often narrow endemics and poorly dispersed (Hughes and Hollingsworth 2008), they make ideal trackers for the biogeography analysis of the mesic flora. The aim of this paper is to describe Begonia species distribution patterns in the Nepal Himalaya, and to interpret these patterns in relation to the climate and topography of the region.

\section{Materials and Methods}

The study was undertaken as a part of revision of the genus Begonia for the Nepal Himalaya; in addition to currently accepted species several new species were found which are annotated in this publication as ineditus, and will be published validly in a forthcoming paper. Specimens were collected from various localities in the Nepal Himalaya during 2005-2008. This made it possible to study all taxa except $B$. megaptera, B. minicarpa, B. nepalensis, B. ovatiflora and B. roxburghii in their natural habitat, where habit, phenology and ecology were noted. The field data was combined with data from herbarium specimens from BM, E, K, K-W, KAH, MICH, TUCH and data from literature records (Hughes and Pullan 2007). DIVA- 


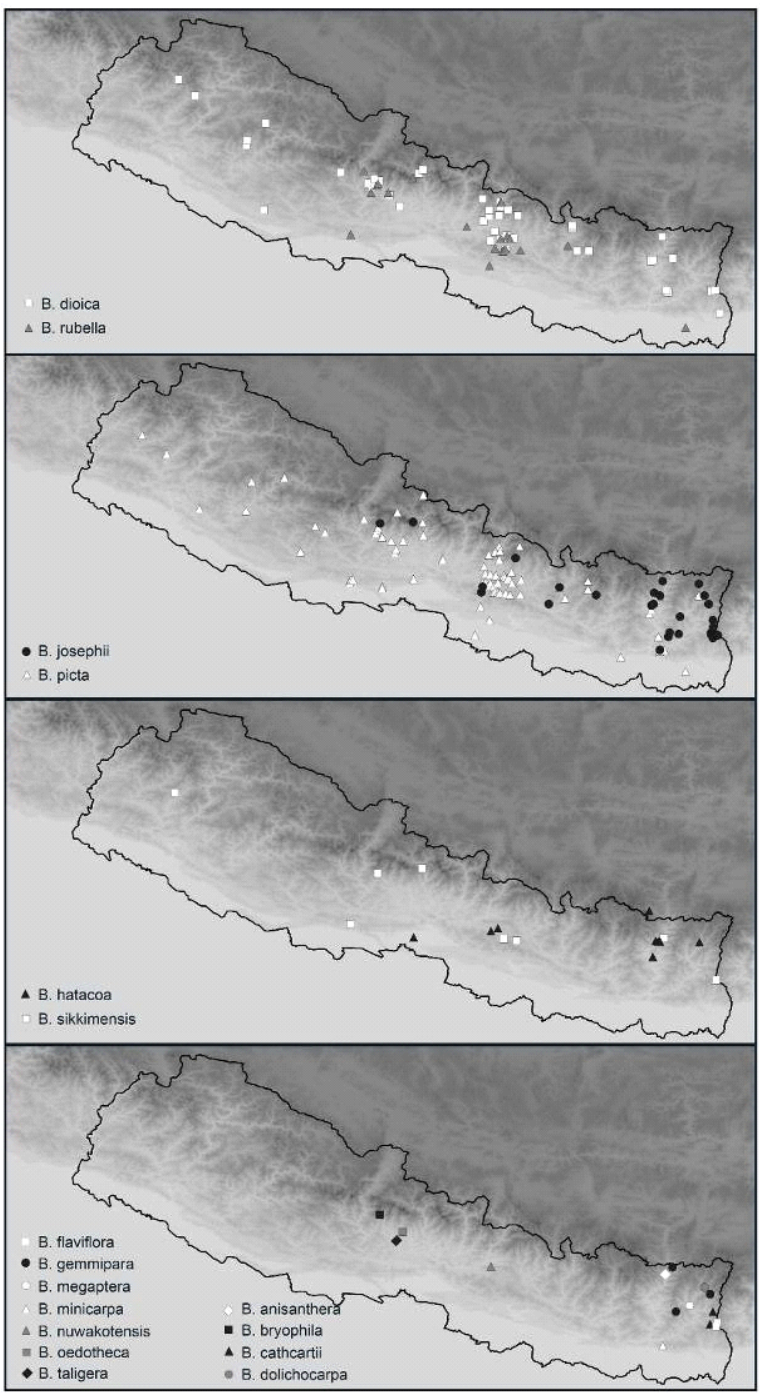

Figure 1. Examples of types of distribution patterns shown by Begonia species in Nepal. Top 2 maps show the most widespread species in Begonia sect. Diploclinium. The next map shows two species from Begonia sect. Platycentrum with the widest distributions in Nepal. The bottom map shows a selection of species with very narrow distributions in Nepal.

GIS (Hijmans et al. 2005) was used to plot and analyze the distribution data. Species distributions were modeled based on 19 climatic variables (BIOCLIM; Nix 1986) and a standard percentile cut-off (95 and 97.5 percentile). Species richness was calculated using two methods, firstly by producing a grid totaling the predicted species distributions for each square. Secondly, species richness was calculated as a summary of species numbers within $100 \mathrm{~km}$ diameter neighborhoods. DIVA-GIS was also used to obtain monthly precipitation figures for each species by querying our geographic localities
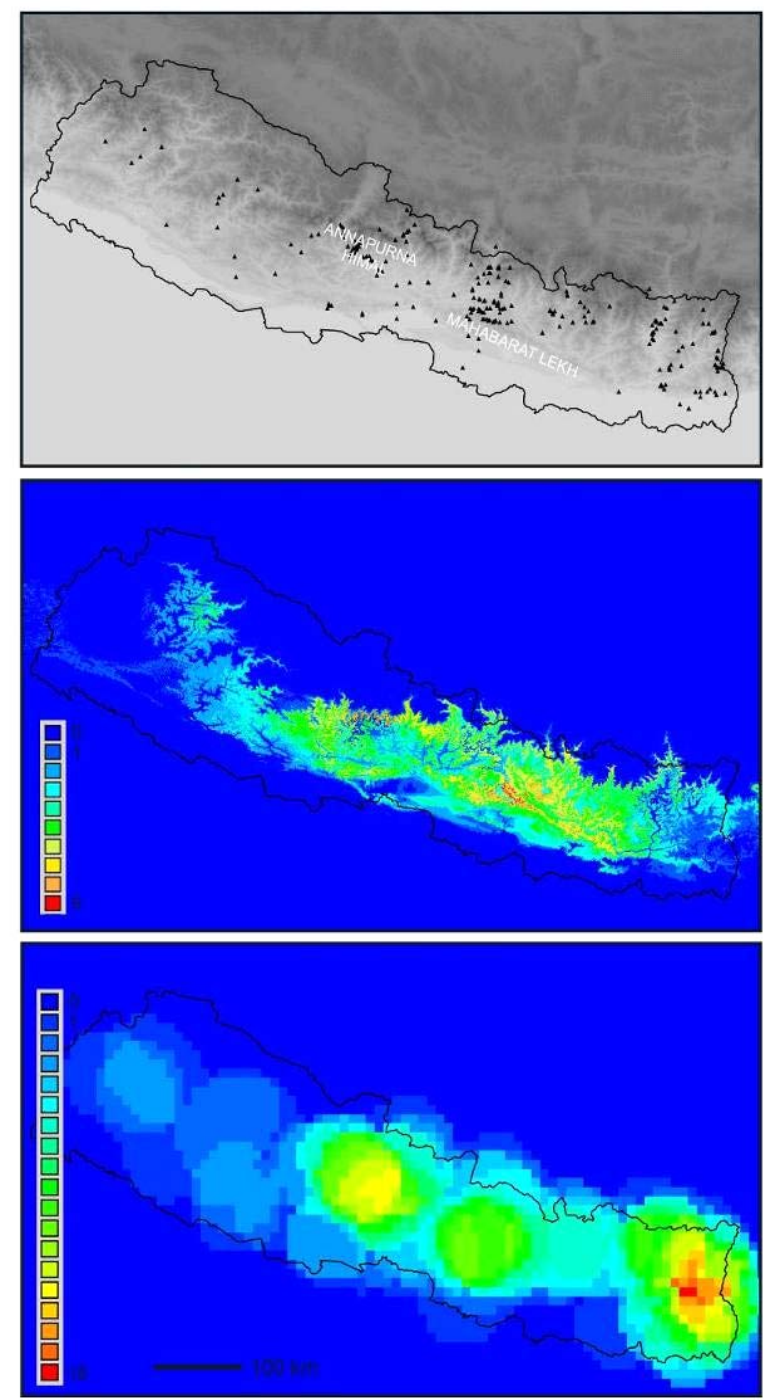

Figure 2. Begonia species richness maps. Top, collection localities of Begonia species; middle, species richness based on modeled species distributions, legend shows number of species expected at each site; bottom, species richness based on summary of species numbers within a $100 \mathrm{~km}$ diameter neighbourhood, legend shows number of species expected within the sampling radius.

with the WORLDCLIM database (Hijmans et al. 2005). Phenology data, expressed as number of flowering observations per month, was calculated from herbarium specimen data.

\section{Results}

A total of 29 species were found in Nepal, 14 from Begonia sect. Diploclinium, 12 from Begonia sect. Platycentrum, 1 from each of Begonia sect. Monopteron., Begonia sect. 


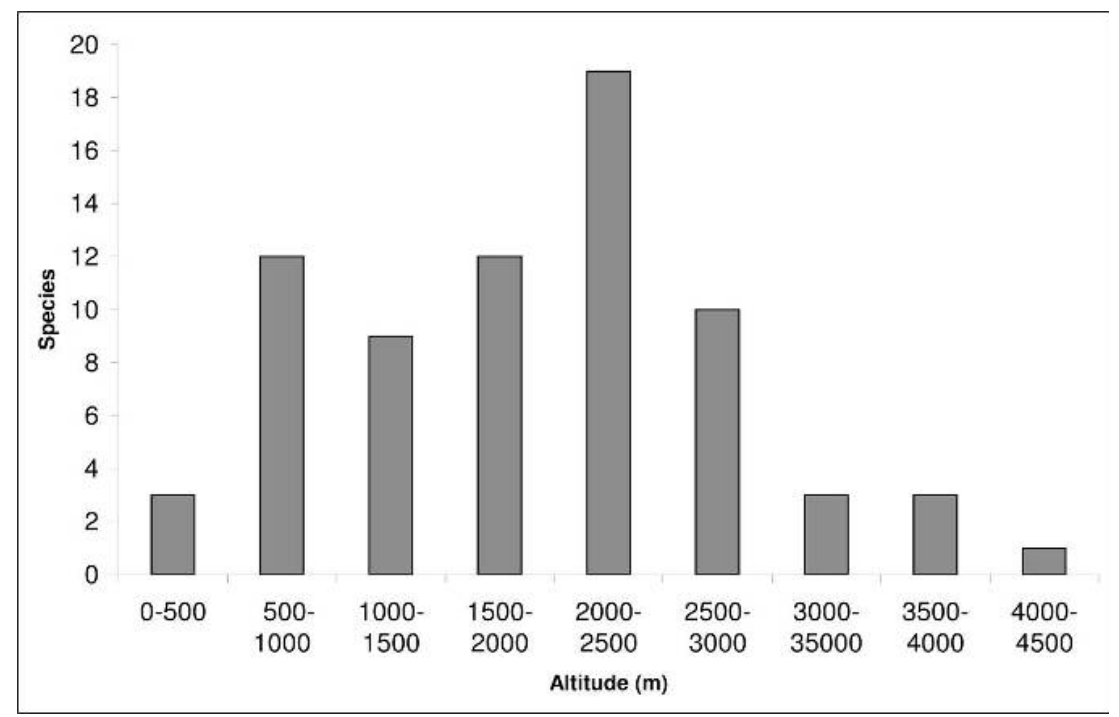

Figure 3. Number of Begonia species observed per $500 \mathrm{~m}$ altitudinal band.

Putseyzia and Begonia sect. Sphenanthera. Of these, 69\% (B. anisanthera ined., B. cathcartii, B. dioica, B. dolichoptera ined., B. flaviflora, B. gemmipara, B. josephii, B. leptoptera, B. hatacoa, B. megaptera, B. minicarpa, B. ovatifolia, B. panchtharensis, B. palmata, B. picta, B. staintonii ined., B. tribenensis, B. sikkimensis, B. nepalensis, B. roxburghii) occur in East Nepal, followed by $65 \%$ of Begonia species ( $B$. annulata, B. bryophila ined., B. dioica, B. flagellaris, B. hatacoa, B. josephii, B. leptoptera, B. manangensis ined., B. megaptera, B. nuwakotensis, B. oedotheca ined., B. ovatifolia, B. palmata, B. picta, B. rubella, B. sinwaensis ined., B. sikkimensis, B. taligera, B. tribenensis) in Central Nepal, and $14 \%$ of species (B. dioica, B. picta, B. rubella, B. sikkimensis) in West Nepal.

A number of the Begonia species in Nepal are known only from 1 or 2 localities (examples shown in Fig. 1); the following are not found outside Nepal and hence are very narrow Nepalese endemics: B. anisanthera ined., $B$. dolichoptera ined., B. managensis ined., B. nuwakotensis, $B$. panchtharensis, B. sinwaensis ined., B. staintonii ined. and B. taligera. Only 3 of these are in Begonia sect. Platycentrum; the remaining 5 are in Begonia sect. Diploclinium. Although Begonia sect. Diploclinium appears to have a propensity for generating narrow endemics, a number of species in the section have very wide distributions in Nepal (Fig. 1, top 2 maps) and beyond, for example B. dioica. B. josephii, B. ovatifolia, B. picta, B. rubella are distributed from the Himalaya region (Nepal, Bhutan, India) to China and Northern Burma. However they remain restricted to the Himalayan range. Two species in Begonia sect. Diploclinium (Begonia picta and B. dioica) extend the range eastward along the Himalaya to Pakistan and Himanchal Pradesh in northern India (Ghazanfar and Aziz 1976; Dang 1979). In contrast, some Nepalese species in Begonia section Platycentrum and the closely allied sections Begonia sect. Monopteron and Begonia sect. Sphenanthera are found outside the Himalayas and extend the range of this group into China, Taiwan, Burma, Thailand and Vietnam.

Considering distributions at the regional level, there is a distinct gradient in species richness across the Nepal Himalaya from west to east (Fig. 2). Only 2 species (Begonia picta and B. dioica) are abundant in the very seasonal and dryer parts of West Nepal. In East Nepal the regional species richness is higher due to both narrow endemics and species which have wider distributions to the west. Grierson (1991) described 20 Begonia species from Bhutan of which 15 species are present in Nepal. In India, 56 Begonia species have been reported with 23 being endemic (Uddin 2007) also of which 15 species are found in Nepal. Bangladesh has eight Begonia species (Ahmed et al. 2008) of which two species, B. megaptera and B. roxburghii, also occur in Nepal. In Flora of China (Gu Cuizh et al. 2007), 173 Begonia species have been described with 141 endemic; 5 species are also found in Nepal. Hughes (2007) listed 57 Begonia species from Myanmar including 9 Himalayan Begonia species (B. cathcartii, B. hatacoa, B. josephii, B. megaptera, B. nepalensis, B. palmata, B. picta, B. sikkimensis and $B$. roxburghii). 


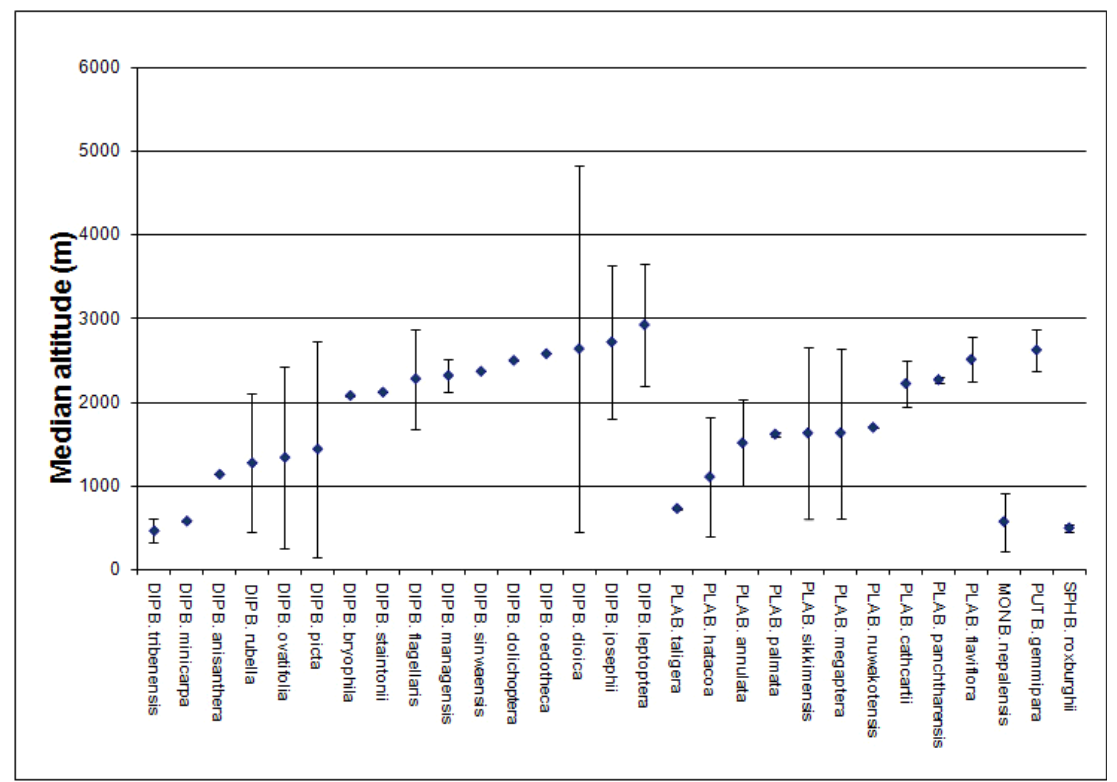

Figure 4. Median and range of altitudes for the occurrence of Nepalese Begonia. DIP, Begonia sect. Diploclinium; PLA, Begonia sect. Platycentrum; MON, Begonia sect. Monopteron; PUT, Begonia sect. Putseyzia; SPH, Begonia sect. Sphenanthera.

The vertical distribution of Begonia species in Nepal ranges from around $500 \mathrm{~m}$ to $4500 \mathrm{~m}$, although most species are found in the range 500-2500 $\mathrm{m}$ (Figs 3 \& 4) in the warm temperate and subtropical belt. The 2 sections with the largest number of species, Begonia sect. Diploclinium and Begonia sect. Platycentrum, have broadly similar altitudinal distributions, although some species in the former section have wider altitudinal tolerances and occur at altitudes of above $3000 \mathrm{~m}$.

The phenology of two largest sections of the genus in Nepal differs. Begonia sect. Diploclinium has negligible flowering before July, when the flowering period starts and lasts for three months until September after which few flowering plants can be found for the remaining 9 months of the year (Fig. 5). In contrast, reasonable numbers of flowering individuals of species in Begonia sect. Platycentrum can be found from April to October, a much longer flowering season; the season both starts earlier and last longer (Fig. 6).

\section{Discussion}

The majority of Begonia species are shade loving succulent hygrophilous herbs, and hence the availability of water and how to cope with its seasonal absence are expected to be major determinants to the shaping the distribution of the genus in areas with strongly monsoonal climates such as Nepal. Sustained monsoon rains commence in June, being preceded by a build up of thundery rainstorms. The origin of the monsoon rains is the Bay of Bengal, and hence the intensity of the rains decreases and its altitudinal onset increases as one travels from east to west across Nepal (Lillesø et al. 2005). The west to east increase in Begonia species richness at the regional scale is correlated with this increased intensity of the monsoon in the east and its onset at lower and warmer altitudes. Local variation in precipitation occurs due to topological effects, such as at the foothills of the Annapurna Himal, which are not shadowed by an area of high altitude to the south and hence receive over $5000 \mathrm{~mm}$ of annual rainfall. This localized variation in rainfall and associated temperature mediation will account for the high species richness predicted in the Annapurna Himal and Mahabarat Lekh regions from modeled species distributions (Fig. 2). The differences observed between the modeled species richness and regional species richness patterns are due to two main factors. Firstly, the regional species richness (Fig. 2, bottom map) is based solely on specimen data and hence missing data for a locality will be interpreted as zero species, leaving many areas for which there are no collections, such as the Mahabarat Lekh, under-recorded. Secondly, only species which have a fairly wide modeled distribution will have an impact on the overall modeled species richness (Fig. 2, middle map), skewing the 


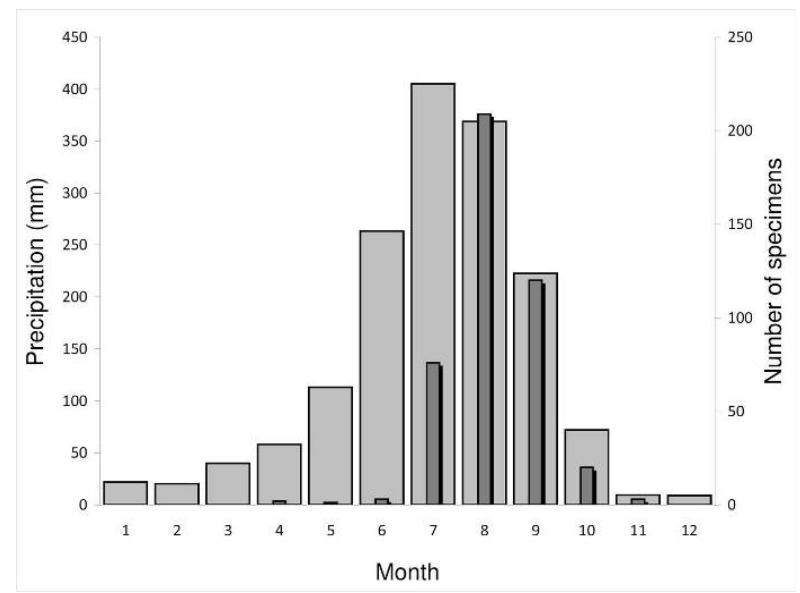

Figure 5. Monthly precipitation (wide pale grey bars) and number of flowering specimens observed (thin dark grey bars) summed for all species in Begonia sect. Diploclinium.

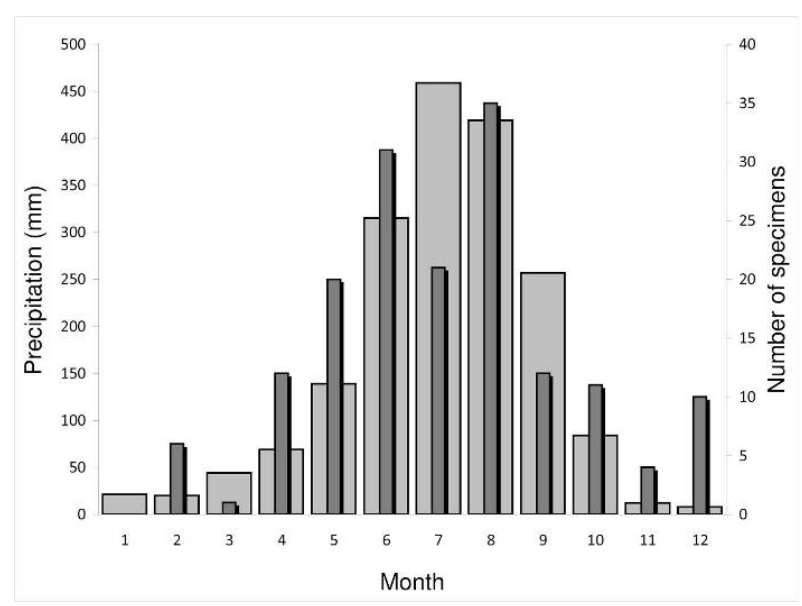

Figure 6. Monthly precipitation (wide pale grey bars) and number of flowering specimens observed (thin dark grey bars) summed for all species in Begonia sect. Platycentrum.

results to areas with higher numbers of co-occurring species whilst not highlighting areas with species which have narrowly endemic and non-overlapping distributions.

The occurrence of several species of Begonia sect. Diploclinium in the far west of Nepal and beyond highlights the ability of species in this section to cope with marked seasonality in precipitation and prolonged periods of drought. These species, in common with their co-sectional relatives in Nepal, are geophytes and resist drought by dying back to a small hidden tuber during the dry season and resprout with the onset of the rainy season. This ability to withstand drought may also explain the higher altitudinal tolerance of some members of this section (Fig. 4). The adaptation to seasonal habitats limits the distribution of Nepalese species in the section to the Himalayan range to the west and east of Nepal and excludes them from areas with more aseasonal rainfall. In contrast, species in Begonia sect. Platycentrum lack a tuber, and although they possess a rhizomatous stem base they do not die back completely during the dry season. Although in the east of Nepal the 2 sections have broadly overlapping distributions, species in Begonia sect. Platycentrum tend to prefer wetter micro habitats such as areas near streams which provide water and humidity even during the dryer months. The adaptation to wetter areas permits some Nepalese species in this section to expand their range into more tropical areas such as Indo-China.

The difference in phenology of Begonia sect. Diploclinium and Begonia sect. Platycentrum (Figs 5 \& 6) is probably linked to their water use ecology. The former will not flower until 1 to 2 months of sustained rainfall have stimulated them to re-sprout and given them time to produce a few leaves from their tuber. By contrast, as species in the latter section remain evergreen, it appears that even a short period of rain can be enough to stimulate flowering, as the plants are in leaf and can take immediate advantage of increased water availability. In addition, earlier flowering means that many plants will have mature fruit capsules by August and September, when the monsoon rains are still heavy. Species in Begonia sect. Platycentrum produce rain-splash fruits which depend on rain drops to release the seeds, in contrast to species in Begonia sect. Diploclinium which produce dry dehiscent capsules and disperse seeds via wind shaking the winged capsules.

The results presented here show that the Begonia flora of Nepal is largely comprised of two sections which differ in their distributions, ecology and phenology. The data show the importance of climatic factors such as the amount and seasonality of precipitation in shaping not only the flowering and fruiting periods of Nepalese plants but also their distribution and species richness. Areas of potential species richness which are currently underexplored, such as the Mahabarat Lekh and areas of the Annapurna Himal foothills have been highlighted. The Himalayan orogeny and development of the monsoon climate have undoubtedly influenced the evolution of Nepalese Begonia, and the genus will be an ideal model for phylogenetic investigations into the temporal and geographic origins of the Himalayan flora. 


\section{Acknowledgements}

The authors thank the curators of BM, E, K, KATH, MICH and TUCH for allowing access to herbarium material; Prof. Stephen Blackmore, Dr. Mark Watson, Dr. Colin Pendry and Martin Pullan of the Royal Botanic Garden Edinburgh for their support; the University Grants Commission (UGC) Nepal and the M.L. MacIntyre Begonia Trusts for providing financial assistance, and the Critical Ecosystem Partnership Fund (CEPF) USA and WWF Nepal for supporting field work. Finally, special thanks go to students of Central Department of Botany, Tribhuvan University and Mr. S.R. Bista for their assistance in the field.

\section{References}

Ahmed Z.U., Hassan M.A., Begum Z.N.T. and Khondker M. 2008. Encyclopedia of Flora and Fauna of Bangladesh. Asiatic Society of Bangladesh, Dhaka, Bangladesh.

Bhuju U.R., Shakya P.R., Basnet T.B. and Shrestha S. 2007. Nepal Biodiversity Resource Book: Protected Areas, Ramsar Sites, and World Heritage Sites. International Centre for Integrated Mountain Development (ICIMOD), Kathmandu, Nepal.

Dang, R. 1979. Flowers of the Western Himalayas. Wilderness Films India.

Doorenbos J., Sosef M.S.M., and de Wilde J.J.F.E. 1998. The Sections of Begonia, Including Descriptions, Key and Species Lists (Studies in Begoniaceae VI). (Wageningen Agricultural University Papers: Wageningen, The Netherlands). Backhuys Publishers, The Netherlands.

Ghazanfar S. and Aziz P. 1976. Begoniaceae. Flora of West Pakistan 96 (1): 1-4.
Grierson A.J.C. 1991. Begoniaceae. In: Flora of Bhutan 2 (A.J.C. Grierson and D.J.Long, eds.), pp. 237-246. Royal Botanic Garden Edinburgh, Edinburgh, UK.

Gu Cuizh K., Tsue-chih, Peng C.I. and Turland N.J. 2007. Begoniaceae. Flora of China 13: 153-207.

Heywood V.H., Brummitt R.K., Culham A. and Seberg O. 2007. Flowering Plant Families of the World. Firefly Books, Ontario, Canada.

Hijmans R., Guarino L., Mathur P. and Jarvis A. 2005. DIVAGIS Version 5.0. http://www.diva-gis.org/

Hughes M. 2007. An Annotated Checklist of Southeast Asian Begonia. Royal Botanic Garden Edinburgh, UK.

Hughes M. and Hollingsworth P. 2008. Population genetic divergence corresponds with species-level diversity patterns in the large genus Begonia. Molecular Ecology 17: 26432651.

Hughes M. and Pullan M. 2007. Southeast Asian Begonia Database. [online] URL: <http://elmer.rbge.org.uk/begonia/ $>$ (accessed 12.6.2010).

Irmscher E. 1925. Begoniaceae. In: Die Naturlichen Pflanzenfamilien, 2nd ed. (A. Engler and K. Prantl, eds.), pp. 548-588. Engelmann, Leipzig. Wilhelm Engelmann.

Lillesø J.P.B., Shrestha T.B., Dhakal L.P., Nayaju R.P. and Shrestha R. 2005. The Map of Potential Vegetation of Nepal - a Forestry/Agroecological/Biodiversity Classification System. Forest and Landscape Development and Environment Series 2-2005 and CFC-TIS Document Series No.110. Forest and Landscape, Denmark.

Nix H.A. 1986. A biogeographic analysis of Australian elapid snakes. In: Atlas of Elapid Snakes of Australia (R. Longmore, ed.), pp. 4-15. Australian Government Publication Service, Canberra, Australia.

Uddin A. 2007. Distribution and status of Indian Begonia L. species. Journal of Economic and Taxonomy Botany 31(3): 591-597. 